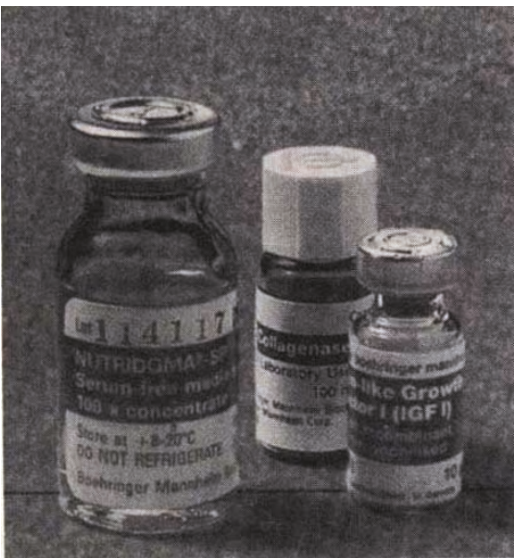

Media Supplements

Nutridoma media supplements from Boehringer Mannheim Biochemicals (Indianapolis, IN) provide the necessary ingredients for good cell growth and high product output. Well-defined, serum-free media with low protein levels $(50-100 \mu \mathrm{g} / \mathrm{ml}$ in one-percent working solutions) make downstream purification easier. Three cell-line-optimized formulations for various hybridomas and lymphoid-derived lines are available.

Write in 802 on Reader Service Card

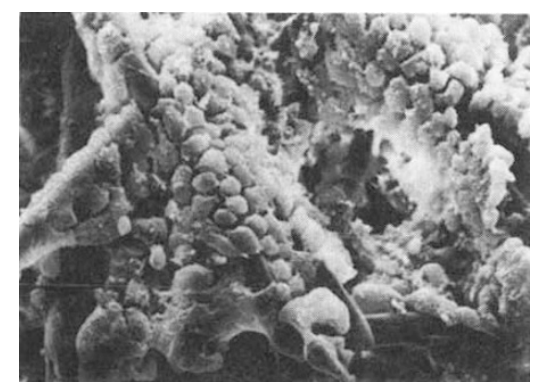

Discontinuous Culture

Designed for both anchorage-dependent and suspension cells, FibraCel Carriers ${ }^{\mathrm{TM}}$ from Sterilin (Hounslow, U.K.) may be used in high-density batch and continuous cultures. The discs are made of a polyester nonwoven fabric with an attached polypropylene screen. Because they support low seeding densities, the discs save labor, consumables, and downstream processing costs.

Write in 804 on Reader Service Card

\section{Serum-Free Medium}

SFM-101 from Kamiya Biomedical (Thousand Oaks, CA) boasts a protein concentration of only $20 \mu \mathrm{g} / \mathrm{ml}$, with no protein other than insulin and transferrin. It supports the growth of hybridoma cells for anti- body production, and can be used for human cells as well as mouse hybridomas. With this medium, the user benefits from hybridoma selection without HAT-medium, and easy collection and purification of cell products from culture supernatants.

Write in 806 on Reader Service Card

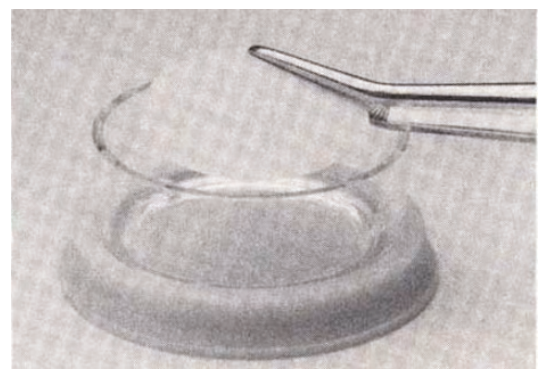

Tissue Culture Plate Insert

Anocell from Anotec (New York, NY) is a porous insert that allows observation of cell growth during cell culture. Anocell uses the company's inorganic membrane, which provides a highly uniform surface for cell attachment and growth. Increased porosity permits free diffusion of ions, macromolecules, and other nutrients to both the basolateral and apical plasma membranes of attached cells.

Write in 810 on Reader Service Card

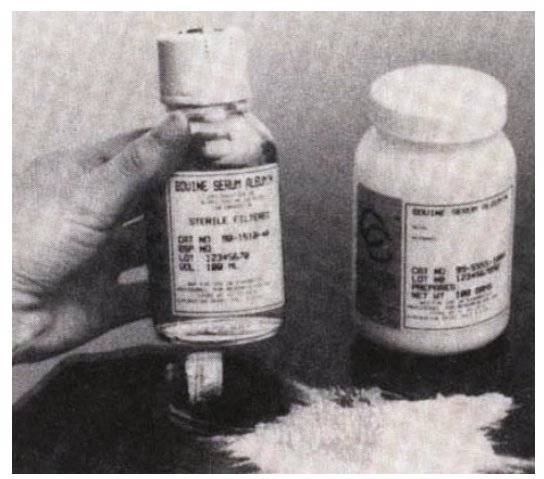

Low-Endotoxin Albumin

Cell Culture Laboratories (Cleveland, $\mathrm{OH}$ ) offers ICP bovine albumin, $>97$ percent pure and low in endotoxin $(<0.1 \mathrm{ng} / \mathrm{mg})$. Particularly effective as a supplement to serum-free media, it can often be used at lower concentrations than other bovine albumins, easing downstream purification. Produced in New Zealand, this product is free of many major viruses, including blue tongue, rhinderpest, foot-and-mouth disease, and bovine spongiform encephalopathy.

Write in 809 on Reader Service Card

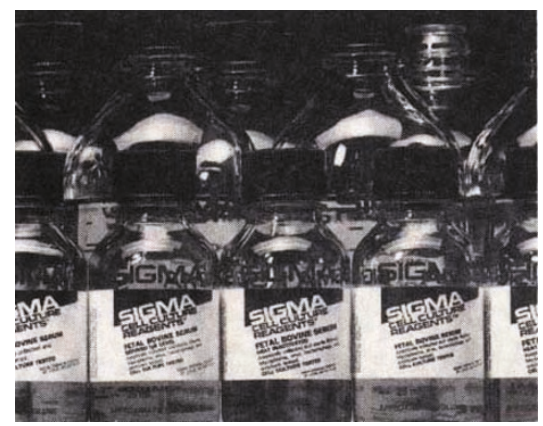

\section{Fetal Bovine Serum}

Sigma's (St. Louis, MO) line of Cell Culture Reagents ${ }^{\mathrm{TM}}$ includes several types of FBS, including heat-inactivated, defined IgG level, dialyzed against $0.15 \mathrm{M} \mathrm{NaCl}$, and aseptically collected, sterile. Sigma also offers a wide variety of other fetal serum products, including equine and calf, as well as cell growth factors that replace serum.

Write in 801 on Reader Service Card

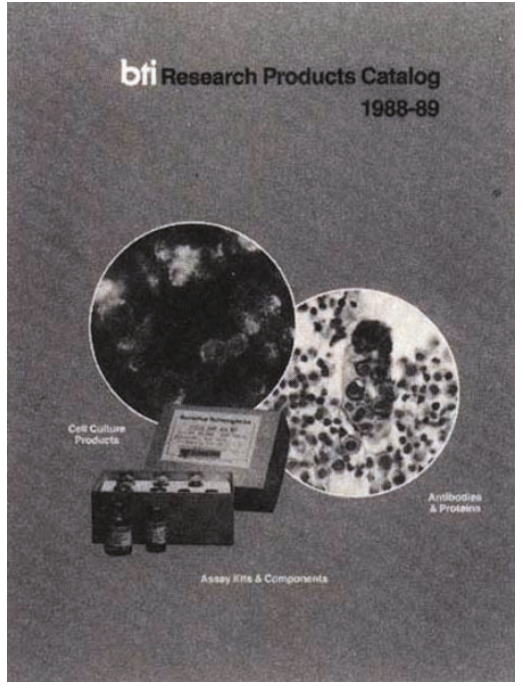

Cell Culture Products

Biomedical Technologies (Stoughton, MA) produces a complete line of cell growth factors, biomatrix components, and cell culture additives for organ and cell culture. The growth factors are EGF, endothelial mitogen, acidic and basic FGF, NGF, PDGF, and TGFs alpha and beta. Many are offered ${ }^{125}$ I-labeled, with kits to quantify them. Also available are biomatrix products: fibronectins, collagen, and laminin. Specialized cell culture additives include platelet-poor plasma-derived serum, hybridoma cellgrowth supplement, and lipoproteindeficient serum.

Write in 808 on Reader Service Card 